Www.jmscr.igmpublication.org

Index Copernicus Value: 79.54

ISSN (e)-2347-176x ISSN (p) 2455-0450

crossrefDOI: https://dx.doi.org/10.18535/jmscr/v7i2.117

\title{
Use of Android Borescope USB Inspection Camera in Neurosurgery As Cost Effective Method
}

\author{
Authors \\ Prof. Y.P. Jacob Grand.M.S.,M.Ch. ${ }^{1}$, P.Pallavan. M.ch. ${ }^{2}$, Prof. M.M.Sankar.M.Ch ${ }^{3}$ \\ S.Rajkumar. $\mathrm{MCh}^{4}$, R.Saravana Santhosh Kumar.M.Ch ${ }^{5}$, \\ A.R.Baskar.D.Ortho.,M.S.,M.Ch ${ }^{6}$, S.S. Aravind.M.Ch. ${ }^{7}$ \\ ${ }^{1}$ HOD,${ }^{2}$ Neurosurgery Post Graduate, ${ }^{3}$ Chief,,${ }^{4,5,6,7}$ Assistant Professor \\ Government Stanley Medical College, Chennai, Tamilnadu, India
}

\begin{abstract}
Introduction and Aim: Neurosurgery is still in primitive stage in developing countries like India particularly in rural areas. Neurosurgical facilities are not available even in some medical colleges also. Neurosurgeons working in rural areas could not afford the state of the art neurosurgical instruments available in developed countries, because of the extreme cost and non availability. We are presenting cost effective Android OTG borescope camera, a cheap instrument available in the market can be used as endoscope instrument as cost effective method in Neurosurgery in rural areas.

Keywords: Endoscope, Android, Borescope, Neurosurgery.
\end{abstract}

\section{Introduction}

Head injury is common nowadays but Neurosurgical facility is not available in rural areas in developing country like India ${ }^{[1,2]}$ endoscopy is used to study the inaccessible areas of the internal architecture of the human body, but commercially available endoscopes in the market are very costly and not readily available for neurosurgeons working in rural areas and district hospitals. Borescope camera for Android cell phones is a cheap and cost effective instrument can be effectively used to inspect Ear, Nose, Throat, scalp wounds, open skull fractures in head injury patients in rural set up and outreached areas.
Materials and Methods

The prototype of Android, Personnel computer USB port camera we used is a type of borescope provided with illumination, flexible long cable with USB port which can be connected with any Android phone or PC installed with Camera FI application programme. We used this cost effective instrument from 2015-2018 for 561 (Males-380, females-181) head injury patients for various modalities. 


\section{JMSCR Vol||07||Issue||02||Page 663-665||February}

Table 1 showing the comparative study of Medical endoscope and USB borescope

\begin{tabular}{|c|c|c|c|}
\hline S.no & $\begin{array}{c}\text { Working } \\
\text { Parameter }\end{array}$ & Medical endoscope & USB borescope \\
\hline 1 & cost & $\begin{array}{c}\text { High(ENT Endoscope(3,4)-15-18000+Cold light source- } \\
\text { 25000+fibro optic cable-10000 INR,camera-40000INR),Neuro } \\
\text { endoscope in lakhs }\end{array}$ & Total cost around 1100 INR \\
\hline 2 & Portability & no & portable \\
\hline 3 & $\begin{array}{l}\text { Advanced } \\
\text { optics }\end{array}$ & $\begin{array}{c}\text { Sellfoc,Hopkinsrod lens(5) lens system and fibro optic } \\
\text { system,cold light source }\end{array}$ & no \\
\hline 4 & Image quality & Real time image & Time delay of 8-12 milliseconds \\
\hline 5 & $\begin{array}{c}\text { Heat } \\
\text { production }\end{array}$ & Working with cold light source, can be used for long time & $\begin{array}{l}\text { LED light source, due to heat } \\
\text { production using time shuld be short } \\
\text { in living subjects. }\end{array}$ \\
\hline 6 & sterility & Chemical sterilisation & Chemical sterilisation \\
\hline 7 & Maintainance & Needs company service & Easy \\
\hline 8 & Availability & Only metropolitan cities & All online shops \\
\hline 9 & Efficiency & Excellent & Fair \\
\hline
\end{tabular}

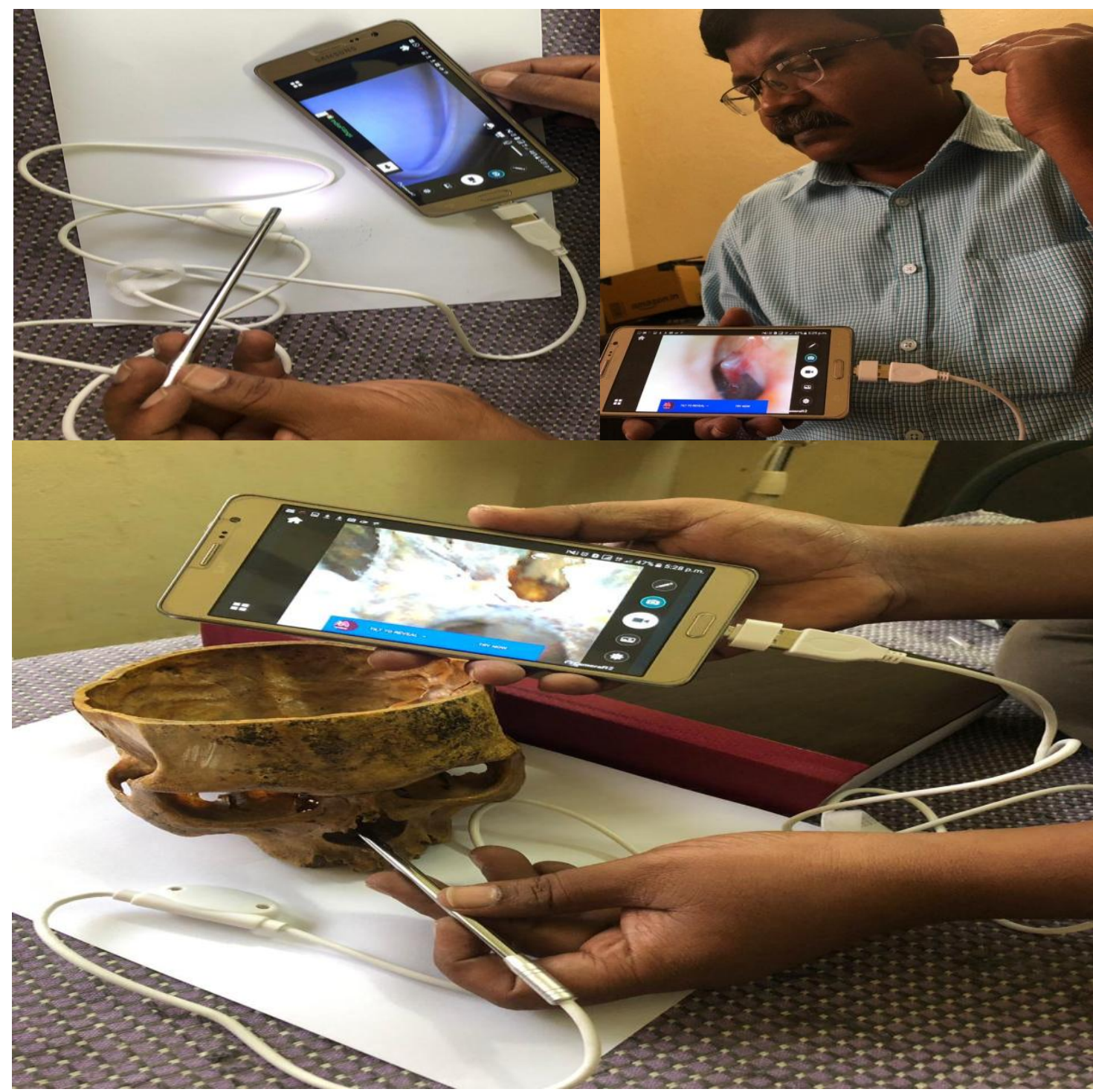

Figures Showing the USB Android/PC borescope, ear drum, sphenoid sinus inner view

\section{Results}

The results are favourable for USB inspection camera, because of ease of use, portable, water resistance and sterilisable. Total cases are 561, ENT and oral examination done in all cases. The compound fracture cases examined are 78 cases, 
Chronic subdural evacuation cases are 54. The disadvantages are the heat production at the tip of the camera end because of the light source which can be reduced by ssalineirrigation. The image produced by the camera is viewed with some time delay, not a real time image produced by medical endoscopes. The advantages are we can take photo or record video

\section{Discussion}

Android and Computer USB inspection camera is a digital camera. This digital inspection camera is 0.3 megapixel, water proof and compatible with USB ports with all Android cell phones ${ }^{[6,7]}$, Laptops and Personal computers. The diameter is only $4.9 \mathrm{~mm}$. This tool can be used safely for inspecting the ear, nose, oral ${ }^{[6,7]}$ and inaccessible area inspection in Head injury patients. Like endoscopes we can sterilise it with glutaraldehyde solution also. After chemical sterilisation it can be used to inspect the interior of burr holes in chronic subdural evacuation cases for presence of membrane and adequacy of evacuation. It is used in Intra cerebral haemorrhage evacuation also to check adequacy of evacuation. In open compound skull fracture cases and scalp laceration cases it is used to examine the status of the skull bone, whether the dura are brain matter is exposed and communicating with the scalp wound or not without disturbing the scalp wound. In heavy scalp bleeding in bevelled scalp laceration it is invaluable in direct inspection of scalp wound even it is smaller in size without much retraction. Because when in retraction the bleeding will stop due to galeal stretch and again bleed if we remove the retraction. It can be used to study the internal anatomy of dry skull bones as a training tool particularly the trans sphenoidal route. Since very cheap can be utilised for cadaver workshop studies.

\section{Conclusion}

When compare with the advantages, the dis advantages are negligible. Due to it's efficiency and more advantages it can be routinely used for all emergency situations like head injury patients particularly in outreached areas in neurosurgical as well as trauma management tool.

Conflict of Interest: The authors have no conflict of interest to declare.

\section{References}

1. Head injuries -a neglected field in India. Editorial National Medical Journal of India(NMH) 4: 53-64 1991

2. Mahapatra AK. Management of Head injury. Neurosciences Today Vol.2: 197204, 1997

3. J.B.Jacobs 100 years of frontal sinus surgery Laryngoscope, 107(1997),pp 1-36

4. P.H.Pownell, J.J. Minoli, R.J. Rohrich Diagnostic nasal endoscopy PlastReconstr Surg,99(1997),pp. 1451-1458

5. C.R. Jennings Harold Hopkins ARCH Otolaryngol Head Neck Surg, 124(1998), p1042

6. Karippacheril JG, Le Cong M Videolaryngoscopy using an Android smartphone: A direct digital technique. Indian J Anaesth. 2016 Feb;60(2):143-5

7. Jung Kweon Bae, MEng (Biomed Eng), Andrey Vavilin, $\mathrm{PhD}$, Joon $\mathrm{S}$ You, $\mathrm{PhD}$, Hyeongeun Kim, BE, Seon Young Ryu, $\mathrm{PhD}$, Jeong Hun Jang, MD, and Woonggyu Jung, PhD Smartphone-Based Endoscope System for Advanced Point-ofCare Diagnostics: Feasibility Study. 